\title{
The right of access to information and national security in the African regional human rights system
}

\author{
Aaron Olaniyi Salau* \\ Lecturer, Faculty of Law, Department of Jurisprudence and International Law, \\ Olabisi Onabanjo University, Ago Iwoye, Nigeria
}

\section{Summary}

October 2016 marked the 35th anniversary of the adoption of the African Charter on Human and Peoples' Rights - the first two decades of which the meaning, normative content and scope of the right of access to information guaranteed by article 9 of the Charter were largely unexplored. However, the implementation bodies of the African Charter subsequently have whittled down challenges posed by the narrow formulation of article 9, its claw-back clause and the undemocratic practices of African regimes in relying on vague and widely-drafted laws to deny access to state-held information on grounds of state security. This article examines the methodologies adopted by the African Commission on Human and Peoples' Rights and the African Court on Human and Peoples' Rights to supplement and entrench a substantive right of access to information compatible with international standards in article 9. The article finds that an overhauled article 9 dictates that the right of access to information held by public and private bodies is a fundamental right, indispensable to the health of a democracy and a means of protecting other rights, especially socio-economic rights. The right may in recognised instances be restricted, including on grounds of national security, only as clearly provided by law to serve a legitimate purpose and as necessary in a democratic society. The article proposes that state parties to the African Charter engage with the logic and reasoning of its implementation bodies to adopt measures and align their constitutional frameworks with the fundamental principles of access to information.

Key words: right of access to information; national security; democratic society; limitation of rights; public interest; article 9 African Charter; African Commission on Human and Peoples' Rights

* $\quad$ LLB LLM (Ile Ife, Nigeria) PhD (Cape Town); niyisalau@yahoo.co.uk 


\section{Introduction}

The right of access to information ${ }^{1}$ is the hallmark of an effective constitutional democracy. ${ }^{2}$ This right is a component of the broader right to freedom of expression recognised in basic instruments of the United Nations (UN) ${ }^{3}$ and regional human rights systems. ${ }^{4}$ The right of access to information has gained recognition as a stand-alone right guaranteed in constitutions and other laws. ${ }^{5}$ The right imposes a duty on the state to facilitate access of everyone ${ }^{6}$ to information held by public bodies ${ }^{7}$ in any accessible form or retrieval systems, howsoever produced. ${ }^{8}$ Nevertheless, international human rights law recognises the significance of varied backgrounds in which human rights including the right of access to information - must be protected. ${ }^{9}$ 'The African human rights system', which is the totality of human rights protection under the auspices of the African Union (AU), ${ }^{10}$ is

1 T Mendel Freedom of information: A comparative legal survey (2008) iii, https:// www.law.yale.edu/system/files/docume...ndel_book_\%2528Eng\%2529.pdf

(accessed 7 October 2017). Freedom of information technically means and is 'commonly understood as the right to access information held by public bodies'. In this article, the 'right of access to information' is used throughout except as otherwise indicated.

2 J Fitzpatrick 'Introduction' in S Coliver \& P Hoffman (eds) Secrecy and liberty: National security, freedom of expression and access to information (1999) xi.

3 Art 19(1) Universal Declaration of Human Rights, UN General Assembly Resolution 217 A (III), 10 December 1948; art 19(1) International Covenant on Civil and Political Rights, UN General Assembly Resolution 2200 A (XXI), adopted 16 December 1966, entered into force 23 March 1976.

4 Art 13(1) American Convention on Human Rights, adopted at San José, Costa Rica, 22 November 1969, OAS Treaty Series 36, entered into force 18 July 1978; art 10(1) European Convention for the Protection of Human Rights and Fundamental Freedoms, ETS 5, adopted 4 November 1950, entered into force 3 September 1953; art 9 African Charter on Human and Peoples' Rights, adopted at Nairobi, Kenya, 26 June 1981, OAU Doc CAB/LEG/67/3 Rev 5, 21 ILM 58 (1982), entered into force 21 October 1986.

5 United Nations Development Programme Right to information practical guidance note UNDP (2004) 8.

6 The extent to which non-citizens or residents in a country have rights of access to information varies from one jurisdiction to another. However, this is the plain meaning of the right. See C Darch \& PG Underwood Freedom of information and the developing world: The citizen, the state and models of openness (2010) 76.

7 Including private bodies executing public functions or utilising state funds. See A Roberts 'Structural functionalism and the right to information' in R Calland \& A Tilley (eds) The right to know, the right to live: Access to information and socioeconomic justice (2002) 28-46.

8 UN Special Rapporteur on Freedom of Opinion and Expression, 1997 Report to the UN Commission on Human Rights.

9 Vienna Declaration and Programme of Action, adopted by the World Conference on Human Rights in Vienna on 25 June 1993, paras 2, 5, 8, 18, 19, $27 \& 38$.

10 Established to replace the Organisation of African Unity (OAU) through the Constitutive Act of the African Union, OAU Doc CAB/LEG/23.15, adopted by the OAU Assembly of Heads of State and Government at the 36th ordinary session of the OAU held on 11 July 2000 in Lomé, Togo, entered into force 26 May 262001 (CAAU), art 2. 
one such system. ${ }^{11}$ Significant similarities and marked differences exist in article 19 of the UN International Covenant on Civil and Political Rights (ICCPR), article 9 of the African Charter on Human and Peoples' Rights (African Charter) and corresponding provisions in comparative regional instruments. ${ }^{12}$ The content, scope and extent to which the right of access to information in practice is respected also differ. ${ }^{13}$ This necessitates an analysis of the guarantee of these rights in the African human rights system, ${ }^{14}$ taking a cue from the emerging praxis in the older UN and Inter-American human rights systems. ${ }^{15}$ For instance, the Inter-American Court has interpreted the right to seek and receive information in article 13 of the American Convention on Human Rights as encompassing the right of access to information subject to imminent threats to national security. ${ }^{16}$ Article 13 differs slightly from article 10 of the European Convention, which protects the right 'to receive and impart information' simpliciter. By contrast,

11 See eg F Viljoen International human rights law in Africa (2012) ch 8; SA Yeshanew \& S Alemahu The justiciability of economic, social and cultural rights in the African regional human rights system: Theory, practice and prospect (2013).

12 Art 13 African Charter; art 10 European Convention.

13 P de Vos 'Grootboom: The right of access to housing and substantive equality as contextual fairness' (2001) 17 South African Journal on Human Rights 258 261-262. The European Court of Human Rights in Leander $v$ Sweden ECtHR 26 March 1987 para 74; Gaskin $v$ United Kingdom ECtHR 7 July 1989 para 52; and Guerra $v$ Italy ECtHR 9 February 1998 para 53, and line of cases, continues to the maintain 'that freedom to receive information ... basically prohibits a government from restricting a person from receiving information that others wish or may be willing to impart to him. That freedom cannot be construed as imposing on a state, in circumstances such as those of the present case, positive obligations to collect and disseminate information of its own motion.' See W Hins \& D Voorhoof 'Access to state-held information as a fundamental right under the European Convention on Human Rights' (2007) 3 European Constitutional Law Review 114 117-118 (reiterating that the words 'in circumstances such as those of the present case' connote that a positive obligation for the state might in certain situations exist).

14 The system's key instruments recognising access to information include the African Charter, art 9; the African Charter on Democracy, Elections and Governance, adopted 30 January 2007, entered into force 15 February 2012, art 19(2) (states' obligation to guarantee 'free access to information'); the African Charter on Values and Principles of Public Service and Administration, adopted 31 January 2011, entered into force 23 July 2016, art 6; the African Youth Charter, adopted 2 July 2006, entered into force 8 August 2009, art 3(d) (states' obligation to provide access to information for young people to learn their rights and responsibilities); the African Charter on Statistics, adopted 4 February 2009, entered into force 8 February 2015, art 2(1) (the Charter provides a policy framework for the collection of statistical data and information); the AU Convention on Preventing and Combating Corruption, adopted 1 July 2003, entered into force 5 August 2006, art 9 (mandating the adoption of 'legislative and other measures' to give effect to the right of access to information); the Protocol to the African Charter on Human and Peoples' Rights on the Rights of Women in Africa.

15 CA Odinkalu 'The individual complaints procedures of the African Commission on Human and Peoples' Rights: A preliminary assessment' (1998) 8 Transnational Law and Contemporary Problems 359361 (footnotes 8-10) (describing the background and some institutions associated with the earlier establishment of the American and European systems).

16 Claude Reyes \& Others $v$ Chile (19 September 2006) Series C 151, para 77 (InterAmerican Court of Human Rights) https://www.corteidh.or.cr/docs/casos/articulos /seriec_151_ing.doc (accessed 10 November 2016). 
article 9(1) of the African Charter modestly guarantees 'the right to receive information'. The pertinent question then is to what extent the African human rights system respects the right of access to information. Can this right be restricted in the interests of national security of states? This article claims that the African human rights system recognises the right, particularly through article 9 of the African Charter, the exercise of which may not be restricted on national security grounds unless, as demonstrably justified by law, for a legitimate purpose and as necessary in a democratic society. To demonstrate the claim, part 1 sets out the discussion's context. Part 2 of the article appraises the development of the right of access to information standards and national security limitations thereto. Part 3 evaluates the right of access to information standards in the African Charter and national security exceptions, while part 4 evaluates legislative compliance by African countries with regional standards enunciated in part 3. Part 5 is the conclusion.

\section{Right of access to information: Development, rationale and normative scope}

The growing importance of the right to information in contemporary times ${ }^{17}$ came about for several reasons. As Bovens argues, citizens' access to information on democratic governance enhances public control of government, which is likely to abuse public power when such access is lacking. ${ }^{18}$ Moreover, the quality of democratic processes is strengthened by public participation in decision making by well-informed citizens. ${ }^{19}$ Therefore, since democracy exists to safeguard the public interest, ${ }^{20}$ a legally-enforceable right to information on how people are governed will boost public confidence in government and enhance accountability. ${ }^{21}$ Furthermore, access to information is a vital tool to combat corruption by making government activities more transparent and the concealment of

17 By 28 September 2017, 117 counties had legislation on the right of access to information while many have adopted constitutions protecting the right. See freedominfo.org, 'FOI Regimes' https://www.freedominfo.org/regions/global/foiregimes/ (accessed 4 October 2017).

18 M Bovens 'Information rights: Citizenship in the information society' (2002) 10 Journal of Political Philosophy 317-341.

19 AS Mathews The darker reaches of government: Access to information about public administration in the United States, Britain and South Africa (1978) 8.

20 A Downs 'The public interest: Its meaning in a democracy' (1962) 29 Social Research 120.

21 Preamble to Council of Europe Convention on Access to Official Documents http:/ /www.conventions.coe.int/Treaty/EN/Treaties/Html/205.htm (accessed 25 August 2013). 
illegalities more difficult. ${ }^{22}$ This is predicated on the fact that official information actually belongs to the people. From another angle, Darch and Underwood posit that freedom of information is important as a leverage right, ${ }^{23}$ a concept traceable to Jagwanth who argued that citizens' ability to enjoy socio-economic rights is enhanced by being able to utilise available information to compel government's performance of its obligations. ${ }^{24}$ Thus, the force of the argument that democracy provides one of the philosophical foundations for human rights $^{25}$ has a greater impact to support the right to information, but the effective realisation of this right often depends on the reading of the relevant provisions.

\subsection{International right of access to information standards}

In 1946, the UN General Assembly initiated the future discourse on the right to information when it stated that '[f]reedom of information is ... the touchstone of all the freedoms to which the UN is consecrated'. ${ }^{26}$ Furthermore, article 19 of the ICCPR provides as follows:

1 Everyone shall have the right to hold opinions without interference.

2 Everyone shall have the right to freedom of expression; this right shall include freedom to seek, receive and impart information and ideas of all kinds, regardless of frontiers, either orally, in writing or in print, in the form of art, or through any other media of his choice.

Although article 19 of the ICCPR did not originally contemplate the right to information, ${ }^{27}$ starting from 1995 UN bodies were able to draw on freedom of expression as encompassing the right to information. For instance, the UN Special Rapporteur on Freedom of Expression stated that '[f]reedom will be bereft of all effectiveness if the people have no access to information', ${ }^{28}$ and has continued to emphasise the fundamental nature of the right to information. ${ }^{29}$ In 1997, the UN Special Rapporteur acknowledged that the right to 'seek, receive and impart information' enshrined in article 19 of the Universal Declaration 'imposes a positive obligation on states to ensure access to information, particularly with regard to information

22 AS Cordis \& PL Warren Sunshine as a disinfectant: The effect of state freedom of information act laws on public corruption http://workspace.unpan.org/sites/ Internet/Documents/Sunshine\%20as\% 20disinfectant.pdf (accessed 14 October 2017).

23 Darch \& Underwood (n 6 above) ch 2.

24 S Jagwanth 'The right to information as a leverage right' in Calland \& Tilley (n 7 above) 3 .

25 M Nowak Introduction to the international regime for human rights (2003) 46.

26 UNGA Resolution 59(1) of 14 December 1946.

27 Mendel (n 1 above).

281995 Report to the UN Commission on Human Rights (UNCHR), UN Doc E/CN.4/ $1995 / 32$ para 35.

29 See ECOSOC Commission on Human Rights Report of the Special Rapporteur, UN Doc E/CN.4/1997/31, para 5 (4 February 1997). 
held by the government in all types of storage and retrieval systems' ${ }^{30}$ In 1999, the UN Special Rapporteur and two other special mechanisms in their Joint Declaration on freedom of information stated: ${ }^{31}$

Implicit in freedom of expression is the public's right to open access to information and to know what governments are doing on their behalf, without which truth would languish and people's participation in government would remain fragmented.

In their 2004 Joint Declaration, the three special mechanisms elaborated further: ${ }^{32}$

The right to access information held by public authorities is a fundamental human right which should be given effect at the national level through comprehensive legislation (for example Freedom of Information Acts) based on the principle of maximum disclosure, establishing a presumption that all information is accessible subject only to a narrow system of exceptions.

The Human Rights Committee (HRC) in General Comment 34 firmly located the right to information among civil and political rights by stating categorically that article 19(2) of the ICCPR embraces the right to information held by public bodies regardless of the form in which the information is stored, its source and production date. ${ }^{33}$ Consequently, Article 19, an activist body, developed nine principles on states' obligations to enact right to information laws in its Principles on Freedom of Information Legislation. ${ }^{34}$ These encapsulate the minimum standards for right to information laws. 'Maximum disclosure' confirms the obligation to release all official information except in clear and narrow exceptions. 'Obligation to publish' establishes the obligation to proactively publish public interest information. The 'promotion of open government' principle recognises states' obligations to tackle government secrecy. 'Limited scope of exemptions' prohibits exemptions that protect government from embarrassment or the exposure of wrongdoing by subjecting non-disclosure to a public interest override. Lastly, a right to information or freedom of information law has primacy over secrecy

30 Report of the Special Rapporteur, UN Doc E/CN.4/1998/40, para 14 (28 January 1998). The Commission on Human Rights welcomed the view in Res E/CN.4/ 1998/42, para 2 (17 April 1998).

31 International Mechanisms for Promoting Freedom of Expression Joint Declaration, adopted 26 November 1999 https://www.article19.org/pdfs/igo-documents/ threemandates-dec1999.pdf (accessed 10 October 2017).

32 Adopted 6 December 2004 https://www.unhchr.ch/huricane/huricane.nsf/0/ 9A56F80984C8BD5EC1256F6B005C47F0?openocument (accessed 2 October 2017).

33 HRC, General Comment 34 para 18.

34 Drawing on international and regional standards, evolving state practice, and the general principles of law recognised by the community of nations. 
laws. The UN Special Rapporteur has endorsed these principles, ${ }^{35}$ but the Inter-American Court of Human Rights made the first regionallybinding judicial decision recognising the right to information as a stand-alone right inculcating these principles. Claude Reyes \& Others $v$ Chile, ${ }^{36}$ the October 2006 landmark judgment of the Inter-American Court, pertains to the Chilean government's failure to document and respond to requests for documentary information on the environmental risks of a logging project, based on a textual interpretation and theoretical analysis of article 13(1), which reads:

Everyone shall have the right to freedom of thought and expression. This right shall include freedom to seek, receive, and impart information and ideas of all kinds, regardless of frontiers ...

The Court declared that the rights to 'seek' and 'receive' information

[p]rotect[s] the right of every person to request access to the information under the control of the state ... and to receive the said information and the positive obligation of the state to provide it ... except in cases in which a legitimate restriction is applied. ${ }^{37}$

The decision significantly opens a vista for the enriching of interregional access to information jurisprudence because regional bodies, including those on the African continent, can draw inspiration from Claude Reyes.

\subsection{African right of access to information standards}

The African Charter provides in article 9:

1 Every individual shall have the right to receive information.

2 Every individual shall have the right to express and disseminate his opinions within the law.

According to the African Commission on Human and Peoples' Rights (African Commission), article 9 signifies that freedom of expression is a basic right vital to personal development and civic participation. ${ }^{38}$ Beyond that, article 9 as narrowly phrased does not guarantee the right to obtain information which the state may not be willing to release. ${ }^{39}$ Nevertheless, this harsh reality has been toned down drastically by the Commission. The Commission is mandated 'to promote human and peoples' rights and ensure their protection in Africa $^{\prime 40}$ and to monitor the Charter's implementation particularly

35 A Hussain Report of the UN Special Rapporteur on the Promotion and Protection of the Right to Freedom of Opinion and Expression submitted in accordance with Human Rights Commission Resolution 1999/36, Doc E/CN.4/2000/63 (5 April 2000).

36 See https://www./justiceinitiative.org/db/resources2?res_id=103448 (accessed 4 October 2017).

37 Claude Reyes \& Others $v$ Chile (n 16 above).

38 Media Agenda v Nigeria (2000) AHRLR 200 (ACHPR 1998) para 54.

39 CE Welch Jr 'The African Charter and freedom of expression in Africa' (1998) 4 Buffalo Human Rights Law Review 112-113. 
through its protective mandate, ${ }^{41}$ which extends over state parties and persons subject to the African Charter. ${ }^{42}$ The African Commission has adopted a creative interpretive approach based on the interrelatedness of rights, ${ }^{43}$ positive obligations and implied rights to develop otherwise poorly-drafted Charter provisions, especially those on socio-economic rights. ${ }^{44}$ As the African Commission rightly observed in Social and Economic Rights Action Centre (SERAC) \& Another $\checkmark$ Nigeria (SERAC): 45

Clearly, collective rights, environmental rights, and economic and social rights are essential elements of human rights in Africa. The African Commission will apply any of the diverse rights contained in the African Charter. It welcomes this opportunity to make clear that there is no right in the African Charter that cannot be made effective.

It would be appropriate to examine each of these three vital concepts further.

\subsubsection{Positive obligations}

Positive obligations emanate from article 1 of the African Charter, which provides:

The member states of the Organization of African Unity parties to the present Charter shall recognize the rights, duties and freedoms enshrined in this Charter and shall undertake to adopt legislative or other measures to give effect to them.

Starting essentially with SERAC, ${ }^{46}$ the African Commission has constantly maintained that article 1 places binding negative and positive obligations on states like comparable international treaties, ${ }^{47}$ although it is sometimes inconsistent in the application of this principle. ${ }^{48}$ The SERAC communication alleged that environmental pollution arising from oil exploration in Ogoniland by the Nigerian government and a foreign company, Shell Petroleum, contaminated food sources, occasioned the loss of livelihoods and risks to human health. SERAC claimed that the respondents refused to inform the Ogonis of the harmful effects of oil production or involve them in the

40 Art 30 African Charter.

41 Arts 45(1)(a), (b) \& (c), (2), (3) \& (4) African Charter; Viljoen (n 11 above) ch 8.

42 Viljoen (n 41 above) 204-205.

43 See the African Charter, 8th preambular paragraph; arts 1-13 \& 14-26.

44 P de Vos 'A new beginning - The enforcement of social, economic and cultural rights under the African Charter on Human and Peoples' Rights' (2004) 8 Law, Democracy and Development 1.

45 (2001) AHRLR 60 (ACHPR 2001) para 68.

46 As above.

47 Association of Victims of Post-Electoral Violence and Another $v$ Cameroon (2009) AHRLR 47 (ACHPR 2009) paras 88, 122-130 (the extent of a state's responsibility for acts of non-state actors); Sudan Human Rights Organisation \& Another $v$ Sudan (2009) AHRLR 153 (ACHPR 2009) (COHRE case) paras $191 \& 248$.

48 INTERIGHTS the International Centre for the Legal Protection of Human Rights 'Our cases' https//.www.interights.org/our-cases/26/index.html (accessed 5 October 2016). 
development of their resources, but deployed military forces to destroy Ogoni houses contrary to Charter protections. The African Commission decided that all rights generate at least four levels of duties - 'the duty to respect, protect, promote, and fulfil these rights' which 'entail a combination of negative and positive duties' ${ }^{49}$ The duty to respect entails non-interference with rights. ${ }^{50}$ The duty to protect requires taking appropriate measures to prevent rights violations. ${ }^{51}$ The duty to promote requires the facilitation of rights enjoyment by relevant means. ${ }^{52}$ The obligation to fulfil dictates the actualisation of rights through direct provision of basic needs and services. ${ }^{53}$ Accordingly, the Commission found Nigeria to be in violation of its positive obligations in terms of article 16 (the right to enjoy physical and mental health) and article 24 (the right to a general satisfactory environment) to take steps, but which it failed to do, by

[o]rdering or at least permitting independent scientific monitoring of threatened environments, requiring and publicising environmental and social impact studies prior to any major industrial development, undertaking appropriate monitoring and providing information to those communities exposed to hazardous materials and activities and providing meaningful opportunities for individuals to be heard and to participate in the development decisions affecting their communities. ${ }^{54}$

\subsubsection{Implied rights}

The African Commission boosted the enjoyment of expressly guaranteed rights by deciding that rights not expressly excluded may be implied or read into the Charter. ${ }^{55}$ Accordingly, the Commission held that the respondents violated the right to housing by forcefully ejecting the Ogonis from their homes. ${ }^{56}$ The Commission stated that '[p]rotection of the family forbids the wanton destruction of shelter' because 'when housing is destroyed, property, health, and family life are adversely affected' and the other way round. ${ }^{\prime}$ Thus, the Commission read into articles 14, 16 and 18 (obligation to protect the family) a right to housing or shelter, which the African Charter does not expressly guarantee. ${ }^{58}$ Similarly, the Commission found that Nigeria had violated the right to food implicit in the rights to life and health, articles 4 and 16 , respectively: ${ }^{59}$

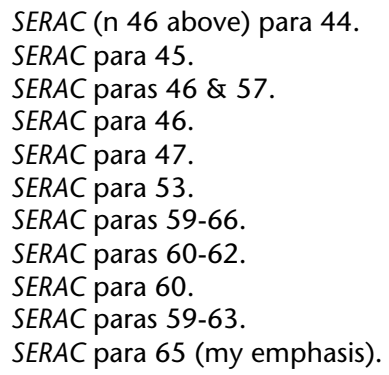


The right to food is inseparably linked to the dignity of human beings and is therefore essential for the enjoyment and fulfilment of such other rights as health, education, work and political participation .... It [the Nigerian government] should not allow private parties to destroy or contaminate food sources, and prevent peoples' efforts to feed themselves.

\subsubsection{Interrelatedness of rights}

SERAC demonstrated the parity of socio-economic and civil and political rights in the African Charter. ${ }^{60}$ The African Commission found the rights to life and family life to be underscored by the protection of human health, the environment, food sources, property, and so forth. ${ }^{61}$ The Commission particularly found that the violation of rights to development (article 24) and health was underscored by a violation of the Ogonis' 'right to be informed of hazardous activities', such as the oil exploration on their land, and laid down the applicable principles as follows: 62

Government compliance with the spirit of articles 16 and 24 of the African Charter must also include ordering or at least permitting independent scientific monitoring of threatened environments, requiring and publicising environmental and social impact studies prior to any major industrial development, undertaking appropriate monitoring and providing information to those communities exposed to hazardous materials and activities and providing meaningful opportunities for individuals to be heard and to participate in the development decisions affecting their communities.

Made in the context of a communication touching on the right to control resources (article 21), these principles presuppose an obligation on government and private bodies to proactively disclose information of public interest for participatory decision making. Fortunately, since SERAC, the African Commission has utilised its promotional mandate to explicitly recognise the right to information through a supplemental soft law to article 9.

\section{Elaborations on the content and scope of the right of access to information in article 9}

Mindful of the narrow scope of article 9 of the African Charter, the African Commission adopted a supplemental, albeit non-binding, Declaration of Principles on Freedom of Expression and Access to Information in Africa (Freedom of Expression Declaration). ${ }^{63}$ The Declaration 'upholds the spirit of article 9 ' and signifies the

60 F Ouguergouz The African Charter on Human and Peoples' Rights: A comprehensive agenda for human dignity and sustainable democracy in Africa (2003) 784.

61 SERAC (n 45 above).

62 SERAC para 53.

63 Originally adopted as Declaration of Principles on Freedom of Expression in Africa at the 32nd ordinary session of the African Commission held in Banjul, The Gambia, 17-23 October 2002, but subsequently amended to include access to 
acceptance in the African human rights system of the right to information as a stand-alone right.

\subsection{Freedom of Expression Declaration}

This Declaration synchronises article 9 with emerging international right to information standards and principles, and establishes the nexus between this right and the right to freedom of expression. The Declaration acknowledges that freedom of expression embraces the right to information necessary for transparency, accountability 'and the strengthening of democracy'. ${ }^{64}$ The Declaration affirms the positive obligation of states to guarantee the right, subject only to clearly-defined rules established by law, ${ }^{65}$ including information held by private bodies, which is necessary for the exercise of any right (Principle IV (2)). The Declaration preserves the principle of proactive disclosure by requiring public bodies actively to publish information of significant public interest 'even in the absence of a request', and protects public interest disclosures. ${ }^{66}$ To remedy any infringement of the right to information, the 'refusal to disclose information' is made subject to appeal to an independent review. ${ }^{67}$ Most importantly, the Declaration articulates the positive obligation of states to amend their secrecy laws to comply with 'freedom of information principles'. In furtherance of the commitment to ensure transparency in governance, the African Commission's Special Rapporteur on Freedom of Expression (Special Rapporteur) has developed a Model Law in tandem with right to information principles.

\subsection{Model Law on Access to Information in Africa}

The Special Rapporteur was established pursuant to the African Commission's promotional mandate, to inter alia monitor states' compliance with right to information (RTI) standards in general and the Declaration in particular. ${ }^{68}$ The second Special Rapporteur, Pansy Tlakula, since her appointment in $2005^{69}$ has facilitated the drafting ${ }^{70}$ and adoption by the Commission of a Model Law on Access to

63 information through the African Commission's Resolution ACHPR/Res.122 (XXXXII) 07, adopted at the African Commission's 42nd ordinary session held 15-28 November 2007 in Brazzaville, Republic of Congo.

64 The Declaration, 4th Preambular Paragraph; Principle I (1).

65 As above, Principle IV (1).

66 As above.

67 As above.

68 Pursuant to Resolution ACHPR/Res.71 (XXXVI) 04, adopted by the African Commission at its 36th ordinary session held 23 November-7 December 2004 in Dakar, Senegal, but subsequently amended by Resolution ACHPR/Res.122 (XXXXII) 07, adopted by the African Commission at its $42 \mathrm{nd}$ ordinary session held 15-28 November 2007 in Brazzaville, Republic of Congo,

69 Appointed pursuant to ACHPR/Res 84 (XXXXV) 05: Resolution on Freedom of Expression in Africa, adopted at the 38th ordinary session of the African Commission held in Banjul, The Gambia, 21 November-5 December 2005.

70 ACHPR/Res 167 (XLVIII) 10: Resolution on Securing the Effective Realisation of Access to Information in Africa (mandating the drafting process), adopted at 48th 
Information for Africa (Model Law). ${ }^{71}$ The Model Law gives effect to states' related obligations under articles 1 and 9 of the African Charter $^{72}$ - to take legislative measures to perfect the right to information inclusive of information privately held and required for the protection of rights. ${ }^{73}$ According to Viljoen: ${ }^{74}$

[T] he Model Law aims to guide national legislators in 'converting' or 'transforming' the open-ended formulation in article 9 into detailed legislative provisions, allowing for an effective national system for accessing information, held primarily by the states, but also by private entities performing public functions.

Article 1 of the Model Law provides an all-embracing definition of 'information' covering documentary, audio-visual, tangible and intangible materials, and regardless of whether the information came into existence before the law's date of coming into operation. It embodies principles such as maximum disclosure and presumption of disclosure (article 2); proactive disclosure (article 7); primacy of right to information law (article 4); and limited exemptions (part III, sections 24-39).

\section{National security exemption, public interest override and African right of access to information standards}

Despite adopting right to information laws, ${ }^{75}$ which are inoperable or deficient, ${ }^{76}$ many African states still have Official Secrets Acts (OSAs) and national security statutes which criminalise the unauthorised disclosure of government information regardless of national security implications. ${ }^{77}$ Furthermore, most of these laws have not been tested judicially for compatibility with African right to information standards.

ordinary session of the African Commission held in Banjul, The Gambia, 10-24 November 2010. The Model Law was officially launched in April 2013.

71 African Commission on Human and Peoples' Rights Model Law on Access to Information for Africa (2013).

72 F Viljoen 'Statement at the launching of the Model Law on Access to Information for Africa' at the 53rd session of The African Commission, 12 April 2013 https:// www.chr.up.ac.za/index.php/ati-news.html (accessed 9 October 2016).

73 Arts 3(a)(i)(ii) \& 12(1) of Model Law.

74 Viljoen (n 72 above).

75 See Africa Freedom of Information website https://www.africafoicentre.org/ index.php/foi-laws \& freedom.org website https://www.freedominfo.org/regions/ africa/ (accessed 17 October 2017).

76 ML Phooko 'An actionable constitutional right of ATI: The case of Southern Africa' in F Diallo \& R Calland (eds) Access to information in Africa: Law, culture and practice (2013) 171-189.

77 Kenya's OSA; Uganda's OSA Cap 302 (1913), Defence Force Act (2004), Criminal Procedure and Evidence Code (1967), Preservation of Public Security Act (1960); Nigeria's OSA 1962, Cap O3 Laws of the Federation of Nigeria (LFN) 2004 and the National Security Agencies Act 1986, Cap N7 LFN 2004; Botswana's National Security Act, 1986, sec 4(1), Public Service Act, 2008, sec 27(3); Zimbabwe's OSA. 
The starting point then to determine the scope of a right to information law's national security exemption are the applicable criteria under the relevant 'harm test' and the public interest override tests. $^{78}$ Accordingly, the Model Law and other Principles come in handy.

The Global Principles on National Security and the Right to Information 2013 (Tshwane Principles), adopted by international law experts in Tshwane, South Africa, in 2013, are relevant. ${ }^{79}$ The Principles aim to ensure 'that information may only be withheld where the public interest in maintaining the information's secrecy clearly outweighs the public interest' in the right to information 80 and 'overriding public interest in disclosure' such that 'withholding on grounds of national security can never be justified' ${ }^{81}$ The public interest override calls for 'balancing the risk of harm [to national security] against the public interest in disclosure', taking due account of relevant factors. Where the public interest in disclosure outweighs the risk of harm, the information sought must be supplied. Furthermore, the non-disclosure of national security information must be prescribed by law, and be necessary in a democratic society for the protection of a national security interest. ${ }^{82}$ Similarly, the Model Law recognises an exemption to the right to information to protect national security and defence (article 30 ), subject to a 'public interest override' against which to test an exemption's legitimacy (article 25), the threshold being 'substantial prejudice to the security or defence of the state' (section 30(1)). Section 30(2) of the Model Law admirably defines 'security or defence of the state' in narrow terms in five categories; that is, military tactics on subversive or hostile activities; defence intelligence or intelligence on subversive or hostile activities; defence intelligence methods or intelligence on subversive or hostile activities; the identity of a confidential source; and the capabilities or vulnerabilities of defence systems excluding nuclear weaponry. Section 30(3) further explains the terms 'subversive or hostile' activities to mean attacks from foreign elements, sabotage, terrorism and espionage. Explicitly defining national security in law is an important practice in democratic societies, but since the Model Law is only a guide, these categories could be further clarified, for instance, concerning nuclear weaponry. The latter would be better addressed by an appropriate national security law or provision enacted in accordance with democratic principles. Nonetheless, the above provisions provide a clear framework for analysis of a national security

78 JM Ackerman \& IE Sandoval-Ballesteros 'Global explosion of freedom of information laws' (2006) 58 Administrative Law Review 101-102.

79 Tshwane Principles https://www.opensocietyfoundations.org/publications/globalprinciplesnational-security-and-freedom-information-tshwane-principles (accessed 7 October 2017).

80 Tshwane Principles (n 79 above), 15th Preambular paragraph \& Principle 3.

81 Principle $10(\mathrm{~A}-\mathrm{H})$ (humanitarian law's violations, government structure, torture, etc).

82 Tshwane Principles (n 79 above), Principle 3. 
exemption. I next examine the extent to which national security exemptions in African RTI laws comply with the region's standards and the relevance of article 9 jurisprudence in this regard.

\subsection{National security exemption to the right to information in Africa: Overview of legislative frameworks}

From merely five countries in 2002, 21 African countries have now adopted RTI or freedom of information (FOI) laws, ${ }^{83}$ and not less than 16 countries have proposed laws ${ }^{84}$ while 18 counties (excluding Morocco) had by 28 September 2017 given constitutional protection to RTI. ${ }^{85}$

Some RTI laws contain primacy provisions specifying the overriding role of the public interest. Starting from West Africa, Liberia's highlyrated Freedom of Information Act of 2010 guarantees to everyone the right to information subject only to the Constitution. The Act exempts documents or records the disclosure of which 'would cause injury or substantial harm to Liberia's security or defence (section 4(2)), and prescribes a public interest override (section 4(8)). Sierra Leone's Right to Access Information Act of 2013 guarantees the right to every person (sections 2(1) and (2)), but permits the non-disclosure of information which 'would or could reasonably be expected to seriously prejudice national security and the defence', while section 12(2) provides a public interest override test. Nigeria's Freedom of Information Act of 2011 provides a weak threshold for exempted national security and defence-related information (section 11(1)), which is what 'may be injurious' while the public interest override is in section 11(2). Compared to Nigeria, Uganda's Access to Information Act of 2005, which gives effect to every citizen's constitutional right to information, recognises a slightly higher non-disclosure threshold where disclosure 'is likely to prejudice' state security (article 5). However, it broadly defines 'security' to mean 'the protection of Uganda against ... crime, criminals and attacks by foreign countries'

83 Freedominfo.org, 'country info' https://www.freedominfo.org/regions/africa/ (accessed 6 October 2017).

84 Art 19 'The right to know in Africa' https://www.article19.org/resources.php/resou rce/38889/en/the-right-to-information-around-the-world (accessed 7 October 2017).

85 Constitutions considered can be found in 'World constitutions illustrated' http:// heinonline.org.ezproxy.uct.ac.za/HOL/COW?collection=cow (accessed 12 October 2017). Art 41 Constitution of the Democratic and People's Algerian Republic (1989) (as amended); art 8 Constitution of Burkina Faso (1991); art 21 Constitution of the Republic of Ghana (1992); art 55(1) Constitution of the Federal Democratic Republic of Ethiopia (1995); art 35 Constitution of Kenya (2010); sec 37 Constitution of the Republic of Malawi (1994); art 18 Tanzania (1977 Amended Constitution); art 34 Constitution of Rwanda; art 32(1)(a) \& (b) Constitution of South Africa 1996; art 15(c) Constitution of the Republic of Liberia (1986); art 41 Constitution of the Republic of Uganda (1995); art 48 Constitution of the Republic of Mozambique (2004); art 24 Constitution of the Democratic Republic of the Congo (2006); Constitution of the Republic of Cameroon (1996); art 245(d) Constitution of the Republic of Cape Verde (2010); art 8 Constitution of the Republic of Senegal (2001); art 19(3) Constitution of Eritrea (1997). 
(section 4). ${ }^{86}$ Similarly, section 3(a) of Kenya's Access to Information Act of 2016 gives effect to every citizen's constitutional right to information, but provides that the right shall be constitutionally limited in respect of information 'likely to' undermine national security (section 6(1)(a)). Unfortunately, the Act's description of national security-related information ${ }^{87}$ is infinitely elastic, covering not only economic matters and the conduct of government affairs, but any 'information whose unauthorised disclosure would prejudice national security' (section 6(2)(a)). A subdued public interest override thus exists in section 6(4) under which disclosure 'may be required ... as shall be determined by a court'.

Angola's Law on Access to Documents Held by Public Authorities 2002 authorises the head of a public body to withhold national security or defence-related information or the existence or nonexistence thereof upon certifying that its disclosure 'would be almost certain to cause serious harm to national security' (article 35(1)). However, such certification is not subject to any judicial review except by the House of Peoples' Representatives before which it must be tabled. Nevertheless, the Proclamation enjoins public officers to apply a public interest override before non-disclosure (section 28). Rwanda's Access to Information Law 4 of 2013 gives expansive rights to information to 'things intended to be published, facts, speeches in reports, mails, circulars, logbooks ... and any other material of public interest by everyone' (article 3 ). The information withheld shall not be published if 'it may destabilise national security' (article 4(1)). Unfortunately, it still gives much discretion to the responsible Minister to issue an order determining which information could destabilise national security (article 5). As well, a public interest override exists in article 6. A person's right to information guaranteed in section 5(1) of the Malawian Access to Information Act of 2016 may be denied where disclosure would 'reasonably be expected' to damage the security or defence of Malawi, while any such refusal must satisfy the public interest override (section 38). South Sudan's Right to Information Act of 2013 protects every citizen's right to information to knowledge, facts or documents of public interest (section 4(3) and 4(4)), but allows the withholding of a record which 'is likely to jeopardise' national defence and security (section 30). It explicitly defines, in line with the Model Law, 'security of the defence of South Sudan' to mean military tactics, defence intelligence, identity of a confidential source, vulnerabilities of weapons, and so on (section 2(a)). Section 22 sets out a public interest override that specifically states that mere security classification is not an exemption category. South Africa's Promotion of Access to Information Act (PAIA) 2 of 2000 gives effect to constitutional protection for the right to information. PAIA is

86 The Ugandan Constitutional Court in Paul Ssemogerere and Zachary Olum $v$ Attorney-General Constitutional Appeal 1 of 2000 affirmed the constitutional right in art 41(1).

87 See art 238(1) of the Constitution. 
considered to be model legislation in Africa considering inter alia that information of which the disclosure 'could reasonably be expected to cause prejudice' to the defence and security, must be disclosed if 'the public interest in disclosure clearly outweighs the harm contemplated' (article 41(1)(a)(i)(ii)). Tunisia's Organic Law 2016-22 of 2016 exempts information prejudicial to national security or defence subject to the 'injury test' and public interest test taking into account relevant factors.

Some states have laws without a public interest override. Burkina Faso's Access to Public Information and Administrative Documents Law of 2014 exempts classified documents and data where disclosure is likely to cause serious damage to national defence and state security as determined by order of the Minister of Defence (articles 36-38), and not subject to any public interest override. Ethiopia's Freedom of the Mass Media and Access to Information Proclamation 590 of 2008 gives effect to citizens' rights to information (articles 11 and 12), but exempts information excluded by any other legislation (article 15), subject to unspecified 'justifiable limits based on overriding public and private interests'. Guinea's Organic Law L 2010/004/Cnt of 2010 protects the right of '[a]nyone, regardless of nationality or occupation' without disclosing any special interest to public information contained in minutes, statistics, directives, instructions, circulars, calls for tenders, and so on, in accordance with article 7 of the Guinea Constitution (article 1). It excludes 'information concerning institutions dealing with state security affairs or those held by them' 'the disclosure of which would seriously undermine the secrets protected by law', but specifies no public interest test. Zimbabwe's Access to Information and Protection of Privacy Act of $2002^{88}$ has been severely criticised for impeding rather than enhancing the right to information. ${ }^{89}$ For instance, it deprives non-citizens and holders of temporary resident, work and student permits of any right to information (section 5(3)). It has no public interest override, while its exemption categories are also overly broad. It debars access to information where disclosure would prejudice the defence and national security and the country's safety or interests (section $17(1)(b)$ ), although it provides for the mandatory disclosure of 'any matter that threatens national security' (section 28(1)(ii)). Article 2 of Niger's Ordinance 2011-22 of 2011 on the Charter on Access to Public and Administrative Documents protects everyone's right to all publicly held data or knowledge existing in written, graphic, video, audio or audio-visual form. It prohibits disclosure of executive documents or information pertaining to national defence secrets, state security or security of persons. Togo's Freedom of Information Act of 2016 guarantees citizens' right to public information and documentation (article 1), excluding security and national defence-related information (article 2). The law has no

88 AIPP https://www.kubatana.net/html/archive/legisl/030611aippaamd.asp?sector= LEGIS (accessed 15 October 2917). 
public override or harm test, but compels a public body to refuse to confirm the existence or to communicate any information that may affect the security of the state (article 38). Unauthorised disclosure of 'non-communicable information' is punishable by administrative penalties and other applicable sanctions.

Tanzania's Access to Information Act of 2016,90 which gives rights to information accorded only to Tanzanian citizens (section 5), exempts information where the disclosure may undermine defence and national security (section 6(2)(a)). The Act disappointedly expands 'information relating to national security' to 'foreign relations or foreign activities' (section $6(3)(d)$ ) and has no explicit public interest override. English translations of Mozambique's Access to Information Act of 2014 are not readily available, but an online article states that the law exempts 'state secrets defined by law'.91 The existence of a public interest override in the law is not clear.

States without RTI laws include Algeria, Cameroon, Chad, Egypt, Eritrea, Ghana, Mauritius, Lesotho, Libya, Mauritania, Somalia, Zambia, Seychelles, and Democratic Republic of the Congo. Nevertheless, the African Commission and African Court can still give effect to RTI at the regional level in these states. The Commission can draw from international treaties and jurisprudence, such as the ICCPR and Claude Reyes \& Others, ${ }^{92}$ and the African Court can enforce international instruments binding on states that have ratified its Protocol and permit personal cases. Moreover, 54 African states have ratified the African Charter. ${ }^{93}$ Notably, the constitutions of some of the countries concerned treat international agreements ratified by them as superior to domestic law ${ }^{94}$ while some constitutions provide that treaties be incorporated into domestic law ${ }^{95}$ or became operative by National Assembly Resolution. ${ }^{96}$ The Constitutions of countries such as Burundi (article 292), Cape Verde (article 12), Egypt (article 151) and Gabon (article 114) provide that ratified treaties enter into force upon publication. In addition, the interpretation clauses of constitutions of the countries concerned also provide for the use of international treaties as interpretative aid. For countries like

90 Freedominfo.org 'Tanzania' https://www.freedominfo.org/wp-content/uploads/ Tanzania-Access-to-Information-Act-2016.pdf (accessed 10 October 2017).

91 Freedominfo.org 'Mozambique President signs FOI legislation; 103rd nation' https://www.freedominfo.org/2015/01/mozambique-president-signs-foilegislation-103rd-nation/ (accessed 18 October 2017).

92 According to arts $60 \& 61$ African Charter.

93 All states signed at least one of Africa's right to information instruments. See OAU/ AU Treaties, Conventions, Protocols and Charters https://www.//au.int/en/treaties (accessed 2 October 2017).

94 'World constitutions illustrated' (n 85 above). Benin (art 147); Burundi (art 292); Cameroon (art 45); Central African Republic (art 69); Chad (art 222); Comoros (art 10); Congo (art 185); DRC (art 215); Djibouti (art 37); Guinea Bissau (art 79); Madagascar (art 82(3)); Mali (art 116); Mauritania (art 80); Senegal (art 98); Togo (art 140); and Tunisia (art 32).

95 AP Blaustein \& GH Flanz (eds) Constitutions of the Countries of the World (2006).

96 As above. 
Cameroon, Chad, Senegal, Burundi, the African Charter recited in the Preambles are explicitly made part of their Constitutions. ${ }^{97}$ For Namibia, domesticated international agreements form part of its law. ${ }^{98}$ The Swaziland Constitution provides that once approved by parliament, self-executing agreements become operative. African right to information standards thus can be enforced creatively through the opportunities provided by such constitutional provisions. Lastly, the Commission's copious and the African Court's incipient jurisprudence on national security restrictions to freedom of expression are also analytically useful.

\subsection{Three-part test of national security restrictions in the African Commission's and African Court's jurisprudence}

This section highlights the African Commission's and Court's jurisprudence on national security restrictions on article 9 rights with a view to showing how these institutions could deal with future RTIrestriction cases. Of course, it is worth noting that independent or judicial scrutiny of non-disclosure becomes relevant after a public or private body, as the case may be, might have applied the harm and public interest override tests, albeit objectionably.

The entire architecture of article 9 prescribes no explicit limitation criteria except the phrase 'within the law' in article 9(2) which prima facie gives leeway for open-ended qualifications to freedom of expression. ${ }^{99}$ However, the Commission has admirably curtailed undue restrictions, and the exercise of unfettered discretion or attempts by states to avoid their article 1 obligations. ${ }^{100}$ Hence, the Commission has acknowledged: ${ }^{101}$

Though in the African Charter, the grounds of limitation to freedom of expression are not expressly provided as in other international and regional human rights treaties, the phrase 'within the law', under article 9(2) provides a leeway to cautiously fit in legitimate and justifiable individual, collective and national interests as grounds of limitation.

Furthermore, based on the Commission's evolutionary jurisprudence on the nature of duties imposed by the African Charter, article 27(2) has become the general limitation clause of the Charter. ${ }^{102}$ Article $27(2)$ provides that ' $[t]$ he rights and freedoms of each individual shall be exercised with due regard to the rights of others, collective security, morality and common interest'. Consequently, the totality of

\footnotetext{
97 As above.

98 Art 144 Constitution of the Republic of Namibia 1990.

99 Welch (n 39 above).

100 Media Rights Agenda \& Others $v$ Nigeria (2000) AHRLR 200 (ACHPR 1998) paras 78-82; Constitutional Rights Project (in respect of Lekwot and Others) $v$ Nigeria (2000) AHRLR 183 (ACHPR 1995); Legal Resources Foundation v Zambia (2001) AHRLR 84 (ACHPR 2001) paras 70, 71.

101 Good v Botswana (2010) AHRLR 43 (ACHPR 2010) para 188.

102 C Heyns 'The African regional human rights system: The African Charter' (2004) 108 Pennsylvania State Law Review 679692.
} 
the Commission's jurisprudence and elaborations regarding restrictions to article 9 reveals that a restriction must be prescribed by 'law', serve a 'legitimate' public interest; and be strictly 'necessary' to achieve that legitimate interest. These are similar to those found in international human rights law and jurisprudence. ${ }^{103}$ I now analyse each requirement in detail.

\subsection{1 'Within the law' (principle of legality)}

A key principle emanating from the Commission's decisions is that the phrase 'within the law' in article 9(2) accommodates only national law that conforms with international standards and does not allow African states to evade Charter obligations ${ }^{104}$ or adopt laws inconsistent with binding international laws. ${ }^{\text {T05 }}$ The Commission has set standards to the effect that

competent authorities should not enact provisions which would limit the exercise of this freedom. The competent authorities should not override constitutional provisions or undermine fundamental rights guaranteed by the constitution and international human rights standards.

In Good $v$ Republic of Botswana, ${ }^{107}$ Botswana argued that states possess absolute national security prerogative under the Charter's articles 23(1) and 12(2) as applicable under Botswana's Immigration Act. A Presidential Order denied the applicant, a prohibited immigrant, reasons for expulsion and judicial review pursuant to the Act. The Commission held that the Order violated the Applicant's rights to information under article 9(1) and access to justice (article 7) and article 1.

Furthermore, 'within the law' implies that freedom of expression may be subjected only to national security restriction in a rule of law

103 Human Rights Committee, General Comment 31, UN Doc. CCPR/C/21/Rev.1/ Add.13 (2004) paras 4-6.

104 Constitutional Rights Project (in respect of Lekwot \& Others) v Nigeria (2000) AHRLR 183 (ACHPR 1995) para 11 concerned the Civil Disturbances (Special Tribunal) Decree, part IV, sec 8(1); Civil Liberties Organisation (in respect of Bar Association) v Nigeria (2000) AHRLR 186 (ACHPR 1995) para 10 concerned the Legal Practitioners' (Amendment) Decree 21 of 1993, sec 23A(1); and Civil Liberties Organisation v Nigeria (2000) AHRLR 188 (ACHPR 1995) concerned the Constitution (Suspension and Modification) Decree 107 of 1993 and the Political Parties (Dissolution) Decree 114 of 1993, sec 13(1). In these decisions in respect of Nigeria, the African Commission found that relevant laws with ouster clauses that allowed the executive branch to operate without judicial check violated arts 7 and 26 of the African Charter.

105 Malawi African Association \& Others $v$ Mauritania (2000) AHRLR 149 (ACHPR 2000), para 102 (affirming that 'within the law' relate to FOE limitations permitted under international norms); Law Office of Ghazi Suleiman $v$ Sudan (I) (2003) AHRLR 134 (ACHPR 2003) paras 37, 42-53, 56-67 (acknowledging Sudan's legitimate security concerns, but declaring Sudan's National Security Act 1994 claim to primacy and eroding of the core of internationally-protected rights as inconsistent with the Charter).

106 Media Rights Agenda (n 100 above) para 15.

107 (2010) AHRLR 43 (ACHPR 2010). 
which gives clear notice of restrictions within its scope. ${ }^{108}$ This excludes the exercise of unfettered discretion upon persons entrusted with the law's execution. ${ }^{109}$ To meet the test, a limiting law, therefore, must be of general application. ${ }^{110}$

\subsubsection{Legitimate purpose (principle of legitimacy)}

To be legitimate, a restriction must apply in clearly-established circumstances and uphold a public interest. In Constitutional Rights Project \& Others $v$ Nigeria, ${ }^{111}$ which concerned the three military decrees which proscribed certain named newspapers and sealed off their premises without trial for unsubstantiated security reasons, the Commission stated: ${ }^{112}$

The only legitimate reasons for limitations of the rights and freedoms of the African Charter are found in article 27(2), that is, that the rights of the Charter shall be exercised with due regard to the rights of others, collective security, morality and common interest.

Again, the African Commission has not applied the Model Law's definition of national security within the context of the right to information, ${ }^{113}$ but has enjoined states not to conflate their national security with interests of public order, public safety and civil security or to excuse gross violations of people's rights in the interests of national security. ${ }^{114}$ Hence, the Commission has repeated that

[t]he reasons for possible limitations must be founded in a legitimate state interest and the evils of limitations of rights must be strictly proportionate with and absolutely necessary for the advantages which are to be obtained. Even more important, a limitation may never have as a consequence that the right itself becomes illusory. ${ }^{115}$

This brings to fore the third aspect of the test.

\subsubsection{Necessity principle}

'Necessity' relates to the concern for proportionality between the extent of the limitation measured against the nature of right involved,

108 Malawi African Association (n 105 above) para 107 (a vague law that created a national security offence of belonging to a secret association without specifying the ingredients of the offence failed the test of legality).

109 Media Rights Agenda (n 100 above) paras 57-59.

110 Constitutional Rights Project \&nd Others v Nigeria (2000) AHRLR 227 (ACHPR 1999) para 44 (ad hominem and retroactive decrees cannot be 'within the law'); Scanlen and Holderness $v$ Zimbabwe (2009) AHRLR 289 (ACHPR 2009) para 117 (ad hominem provisions of the Zimbabwean Access to Information and Protection of Privacy Act not 'within the law').

111 (2000) AHRLR 227 (ACHPR 1999).

112 SERAC (n 45 above) para 41; COHRE case (n 47 above) para 165.

113 However, see the COHRE case (n 47 above) para 171 (holding that 'national security examines how the state protects the physical integrity of its citizens from external threats such as invasion, terrorism, and bio-security risks to human health').

114 Scanlen and Holderness (n 110 above) paras 109-110.

115 Legal Resources Foundation (n 100 above) para 72. 
and aims to prevent unreasonably excessive limitations. ${ }^{116}$ The African Commission has consistently affirmed that restrictions must be as minimal as possible such that the right's infringement is not more than strictly necessary to achieve its desired objective. ${ }^{117}$

In Media Rights Agenda, the Commission held that barring the publication of information that creates a real danger to national security, the prohibition of criticisms of official policy violated article $9(2)$ and was non-compliant with article $27(2) .{ }^{118}$ The Commission also upheld the standard that

[t]he reasons for possible limitations must be founded in a legitimate state interest and the evils of limitations of rights must be strictly proportionate with and absolutely necessary for the advantages which are to be obtained. ${ }^{11}$

In Constitutional Rights Project \& Another v Nigeria, ${ }^{120}$ Nigeria's State Security (Detention of Persons) (Amendment) Decree 14 of 1994 permitted indefinite detention for acts 'prejudicial to state security or the economic adversity of the nation', and conferred the sole discretion to determine the interest of state security on the executive. The law denied the right to habeas corpus and judicial remedy for the infringement of rights. These measures were held to be extreme to fulfil the objective of maintaining public peace and a violation of the Charter. $^{121}$

Furthermore, any limitation on rights should be 'the least restrictive measures possible' to achieve that need, ${ }^{122}$ and be rationally related with its purpose, ${ }^{123}$ although the African Commission sometimes endorses the 'less restrictive means' approach of putting a limitation's legitimate aim into effect. ${ }^{124}$ Notwithstanding these robust interpretations, the Commission's lacks power to implement its recommendations, often disregarded by states, prompting the setting up of an African Court. ${ }^{125}$

116 Scanlen and Holderness (n 110 above) paras 94-98 (the Zimbabwean government's compulsory yearly licensing scheme for journalists aimed at preventing journalists from 'spreading falsehoods' was found to disembowel the right to receive information and excessive).

117 Amnesty International \& Others $v$ Sudan (2000) AHRLR 297 (ACHPR 1999) para 80.

118 Media Rights Agenda (n 100 above) paras 73-75.

119 Media Rights Agenda para 69.

120 (2000) AHRLR 235 (ACHPR 1999).

121 Constitutional Rights Project (n 120 above) paras 33-35.

122 COHRE case (n 47 above) para 214.

123 Interights \& Others v Mauritania (2004) AHRLR 87 (ACHPR 2004) paras 64-75.

124 Zimbabwe Lawyers for Human Rights \& Associated Newspapers of Zimbabwe $v$ Zimbabwe (2009) AHRLR 235 (ACHPR 2009) paras 176-180; Interights (n 123 above) paras 64-75 (the dissolution of a newspaper and seizure of its properties found to be disproportionate to the nature of a national security offence committed when lesser punishments are available); Prince $v$ South Africa (2004) AHRLR 105 (ACHPR 2004) (a 'less restrictive means' required in the Constitution of the Republic of South Africa, 1996, sec 36).

125 EG Nalbandian 'The challenges facing African Court of Human and Peoples' Rights' (2007) 1 Mizan Law Review 75. 


\subsubsection{African Court's jurisprudence on restrictions to freedom of expression}

The African Court was established under article 1 of its enabling instrument $^{126}$ to provide effective remedies, ${ }^{127}$ to complement and re-inforce the protective mandate of the Commission. ${ }^{128}$ The Court has jurisdiction concerning the interpretation and application of its Protocol, the African Charter, and other human rights instruments ratified by state parties, ${ }^{129}$ including requests for legal advisory opinions by the AU or AU member states. The Court adjudicates cases from non-governmental organisations (NGOs) recognised by the $A U$ in accordance with article $4(1)^{130}$ and from individuals against state parties that have accepted its individual jurisdiction in terms of article 34(6) of its Protocol. ${ }^{131}$

Although the African Court is yet to definitively pronounce on the right to information and national security retractions thereto, it has shown an earnest desire to expand the scope of freedom of expression and constrain restrictions thereof, ${ }^{132}$ which portend hope that it would apply analogous principles to the right to information determinations in future. For instance, in Tanganyika Law Society, Legal and Human Rights Centre \& Rev C Mtikila v Tanzania, ${ }^{133}$ the Court said:

[T]he Commission has stated that the 'only legitimate reasons for limitations to the rights and freedoms of the African Charter' are found in article $27(2)$ of the Charter. After assessing whether the restriction is effected through a 'law of general application', the Commission applies a proportionality test, in terms of which it weighs the impact, nature and extent of the limitation against the legitimate state interest serving a particular goal. The legitimate interest must be 'proportionate with and absolutely necessary for the advantages which are to be obtained'.

126 Protocol to the African Charter on Human and Peoples' Rights on the Establishment of the African Court on Human and Peoples' Rights OAU/LEG/MIN/ AFCHPR/PROT(III), adopted in June 1998, entered into force 25 January 2004, reprinted in (1997) 9 African Journal of International and Comparative Law 953 (African Court Protocol).

127 Art 27(1) African Court Protocol.

128 Art 2 African Court Protocol.

129 Arts 3 \& 7 African Court Protocol.

130 Request for Advisory Opinion by The Centre for Human Rights of the University of Pretoria and The Coalition of African Lesbians 002/2015 Advisory Opinion 28 September 2017 https://www.en.african-court.org/images/Cases/Judgment/ 002-2015-African\%20Lesbians-\%20Advisory\%200pinion28\%20September\%202017.pdf (accessed 12 October 2017).

131 Art 5(3) African Court Protocol; Application 1/11 Femi Falana $v$ The African Union, Report on the Activities of the African Court on Human and Peoples' Rights (21-25 January 2013).

132 Application 4/2013, Lohé Issa Konaté $v$ The Republic of Burkina Faso (freedom of expression in art 9 of the African Charter extends to the publication of information critical of public officials, but criminal sanctions thereto are illegal and contrary to the spirit of art 9 and international law).

133 Applications 9/2011\& 011/2011 (judgment of 2013). 
The African Court thus affirmed the African Commission's rights restrictions jurisprudence.

\section{Conclusion}

Through creative interpretations of the open-ended provisions of article 9 of the African Charter, the African Commission has succeeded in clarifying the normative content of the right to information as a basic right, and as instrumental to other rights' protection, particularly socio-economic rights. In deciding communications, and through its Special Rapporteur on Freedom of Expression and Access to Information in Africa, the Commission has elaborated the normative scope and permissible restrictions on the right to information in article 9 in declarations and other soft law instruments. Article 9 of the African Charter certainly permits states to adopt restrictive measures 'within the law' the normative requirements of which are not enumerated unlike comparative human rights provisions. Furthermore, national security protection is not expressly mentioned as a ground for restrictions on the right to information, and the African Charter nowhere requires limitations of rights to be necessary in a democratic society. Notably, the Commission has developed a notion of national security compatible with international human rights law. The Commission has established that the assertion of national security interests by states must be strictly scrutinised. The Commission has creatively laid down criteria comparable with those developed in international human rights law for permissible restrictions on access to information, including on grounds of national security. As can be deduced from its jurisprudence, the Commission has decided that restrictions on the right to information in the interests of national security must be within the law, serve a legitimate public interest and be proportionate for its objective.

The potential of the Commission's recommendations and declarations to protect the right of access to information is seriously hampered by their non-legally binding effect. Fortunately, since the African Court can provide effective remedies, it is hoped that it can effectively police wrongful denials of access to information if its current progress is anything to go by. Hopefully, state parties will now show a greater desire to comply with the Commission's promptings to adopt measures to implement its recommendations, ratify relevant treaties and adopt relevant laws or amend existing domestic laws in compliance with right to information principles as embodied in the Model Law and other relevant international standards. Furthermore, state parties to the African Charter are enjoined to seriously engage with the logic and reasoning of the African Commission and African Court to adopt measures and align their legal frameworks with the fundamental principles of access to information. 